\title{
Measuring the Satisfaction of Residents of Mehregan Township of Mashhad from Sustainable Housing Perspective
}

\author{
Medindo a satisfação dos moradores do município de Mehregan, em \\ Mashhad, na perspectiva da habitação sustentável
}

\section{Mohammad Reza Daime $\operatorname{Kar}^{1}{ }^{(\mathbb{D})}$, Mohammad Ali Ahmadian' ${ }^{1(\mathbb{D}}$, Katayoun Alizadeh ${ }^{1(\mathbb{D})}$ Hossein Hataminezhad ${ }^{1}$ (I)}

'Islamic Azad University, Mashhad, Iran.

\begin{abstract}
Demographic developments in Mashhad and surrounding rural areas which are now considered urban break points It is well established that these areas have become centers of attraction for low-income immigrants who intend to migrate to Mashhad, as well as low-income urban strata that have previously lived in Mashhad. Since all four types of worn-out urban textures, including urban heritage, non-urban, marginal and rural urban textures, are the middle and lower decay habitats, "The 5000 unit project of Mehregan Town of Mashhad" has played an important role in the physical and functional organization of these tissues and responding to the needs of the poor. In view of the above, and several years after the project was inaugurated, the superstructure and infrastructure problems of the project are the subject of research in this research. The research method in this study was descriptive-analytical and applied. According to the number of households in the city that formed the statistical population of the study, and based on Cochran's formula, the sample population was 366 persons. Also, Delphi method has distributed 32 questionnaires to expert experts. Descriptive and inferential statistical analysis of completed questionnaires and experts has been done with the help of nonparametric and parametric statistical methods. The results of field surveys showed that the observed frequency of low-satisfaction residents was 222 and above all, so it is safe to say that $95 \%$ of respondents are not satisfied with their residence in Mehregan town. It is believed that the residential units constructed in Mehregan town of Mashhad have poor compliance with the standards and standards of sustainable housing.
\end{abstract}

Keywords: Satisfaction; Sustainable housing; Sustainable urban development; Marginalization; Mehregan Township of Mashhad 


\section{RESUMO}

Desenvolvimentos demográficos em Mashhad e áreas rurais circunvizinhas que agora são consideradas pontos de ruptura urbana Está bem estabelecido que essas áreas se tornaram centros de atração para imigrantes de baixa renda que pretendem migrar para Mashhad, bem como estratos urbanos de baixa renda que anteriormente morava em Mashhad. Como todos os quatro tipos de texturas urbanas desgastadas, incluindo herança urbana, texturas urbanas não urbanas, marginais e rurais, são habitats de decadência média e baixa, "O projeto da unidade de 5000 unidades da cidade de Mehregan, Mashhad" desempenhou um papel importante. a organização física e funcional desses tecidos e a resposta às necessidades dos pobres. Tendo em vista o exposto, e vários anos após a inauguração do projeto, os problemas de superestrutura e infraestrutura do projeto são objeto de pesquisa nesta pesquisa. O método de pesquisa neste estudo foi descritivo-analítico e aplicado. De acordo com o número de domicílios da cidade que formaram a população estatística do estudo, e com base na fórmula de Cochran, a população da amostra era de 366 pessoas. Além disso, o método Delphi distribuiu 32 questionários para especialistas. A análise estatística descritiva e inferencial dos questionários e especialistas preenchidos foi realizada com a ajuda de métodos estatísticos não paramétricos e paramétricos. Os resultados de pesquisas de campo mostraram que a frequência observada de residentes de baixa satisfação era 222 e, acima de tudo, portanto, é seguro dizer que $95 \%$ dos entrevistados não estão satisfeitos com sua residência na cidade de Mehregan. Acredita-se que as unidades residenciais construídas na cidade de Mashhad, em Mehregan, não cumpram com os padrões e padrões de habitação sustentável.

Palavras-chave: Satisfação; Habitação sustentável; Desenvolvimento urbano sustentável; Marginalização; Município de Mehregan; Mashhad1

\section{INTRODUCTION}

2007 is the first year in human history that more than half of the world's population has lived in cities, and in the same year we have seen the population of the suburbs cross over one billion people, "one out of every three people" (KEARNEY, 2006). The emergence of the industrial revolution, the rise of living standards, the invention of the automobile and the advancement of transportation technology have led to the rapid growth of cities after World War II, and with the rapid growth of the world's population and its focus on cities, the concept of sustainable urban development as an essential factor influencing The long-term perspective of human societies has been raised (GHARAKHLOU, 2006).

On the other hand, rapid urban development has influenced human life in different decades of social, economic, cultural, political, environmental and other aspects. The emergence of sustainable development, as the main motto of the Third Millennium, is also due to the impact of cities on the extent of biosphere and different aspects of human life (HATAMI NEJAD, 2005). As the urban population grows, problems and problems arise, one 
of which is the habitat and housing. It is true that housing is in a state of disrepair in the present situation, and a large mass of our households are in conditions like homeless, cramped, and unwell housing (ATHARI, 2005).

Sustainable development means providing solutions to physical, social and economic technical patterns that address issues such as unnecessary population growth, poverty, resource depletion, and interference with the Earth's ecosystem and in result prevents damage from the adverse effects of environmental degradation (ZABETIAN, 2017). In fact, the general concept of housing is not a residential unit, but rather the whole residential environment (RAFIEIAN, 2009). The concept of housing, in addition to the physical location, encompasses the entire residential environment and has a wide variety of dimensions and beyond a physical shelter (POURMOHAMMADI, 2006). In housing, basic human needs are satisfied, and thus, affect human life quality and can be linked to life assurance (MALEKI, 2009: AZADKHANI, 2016).

Therefore, the need to pay attention to housing and its planning for sustainable urban development in the context of national, regional, and urban planning is increasingly felt to benefit from the knowledge and planning techniques and problems of residents. And thus provide them with a peaceful and green environment with security, comfort and prosperity. Housing in Iran in the last century and more precisely after the development of modernity and the prevalence of cultural, economic and social principles and rules of the developed countries, especially after the land reform and the white revolution and rapid urban development has become a problem and Homelessness and malnutrition have been most likely to affect low-income groups (MAHMOUDI, 2009).

Also in the urban areas of Iran and consequently in Mashhad, structural changes in the country, especially after the economic and social changes of the Second Pahlavi era known as the White Revolution and the increasing role of oil in the economy, have caused social changes and transformed attitudes (AZIZI, 2004). Later, other factors such as land and housing policies at the beginning of the revolution, the outbreak of war, and encouraging policies of population growth continued and sometimes exacerbated migration and urban sprawl, and these transformed the housing problem into a housing crisis (ASADPOUR, 2006). 
On the other hand, the city of Mashhad as a political and economic center of the province has always been the focus of immigrants and whenever the city has not been able to attract them, the surrounding rural areas, such as the inactive valve of the overflow have attracted them, the biggest problem this time has been the population in the housing issue. Under such circumstances, low-income households are often pushed to the margins of housing programs and even in many cases to the periphery of cities and rural areas to provide housing and adapt to housing prices. Demographic developments in the city of Mashhad and the surrounding rural areas that are now considered as disassociated areas of the city confirm that these areas are migrating centers for low-income immigrants who intend to migrate to Mashhad, as well as low-income groups. The income of the city formerly residing in Mashhad has become more and more expensive due to development constraints, land and housing prices rising sharply, and Every day the number of households that can afford to live in Mashhad is reduced in terms of housing costs. Therefore, planning and policies should be revised to address the problem of housing, and especially housing for low-income groups, in the light of the foregoing. Mashhad has a lot of worn-out sections of downtown, informal settlements and rural backgrounds. Since all four types of worn-out urban textures include urban heritage, non-urban heritage, marginal and urban village textures are the habitat of the middle and lower deciles of the community and given the housing shortage are predominantly for low-income groups, they also play an important role in the physical and functional organization of these tissues. Given all of the above, and several years after the inauguration of Mehr Housing of Mehregan Township, the problems of the superstructure and infrastructure of Mehr Housing plan of Mehregan have concerned all residents. Lack of asphalt pavements, early filling of sewage wells due to impermeable soil, cracking of walls and improper placement of settlements are problems in this area. Therefore, measuring the satisfaction of residents of Mehregan Township with regard to compliance with sustainable habitation in the study area is one of the essential issues of integrated urban management and successful metropolis of Mashhad. 
Figure 1- Residential Satisfaction Model

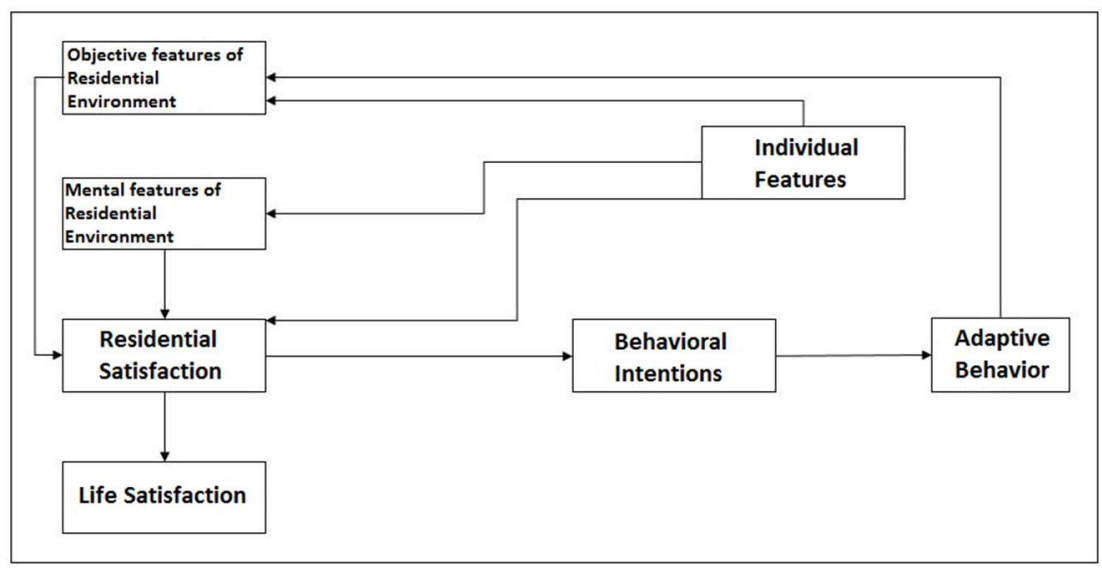

Source: Authors (2020)

\section{METHODOLOGY}

The methodology of this study is descriptive-analytical in nature and applied type. Because based on the defined variables and indicators, it seeks to measure satisfaction in Mehregan Mehr Housing. Data collection was done by field observation and questionnaire and data analysis according to different parametric and nonparametric statistical methods such as Spearman correlation coefficient. Also, the Cochran formula was used to determine the sample size, taking into account the total population of Mehregan Township in the Census of 2016, which is equivalent to 8000 , which is equivalent to 2715 households residing in the Cochran formula. The following equals 366 sample questionnaires, all of which have been questioned and statistically analyzed by simple random distribution. In this, I have used the evidence and evidence available in my home literature for theoretical means. Available in Mehregan Township of Mashhad and the Department of Housing and Urban Development and other organs entries have been made. Also by studying and reviewing the background documents the necessary maps were collected in the city and then all the definitions and experiences in the study of visual management were collected by reading books and scientific journals. Then we summarize and analyze quantitative data from descriptive statistical methods (using descriptive and geometric and visual representations, frequency distribution tables and distribution ratios) and inferential (Pearson ' $r$ ' test, 
regression, one way ANOVA or Fisher ' $f$ ' or Chi-square test, etc. are used for statistical analysis and tests in software, Excel and SPSS.

\section{INTRODUCING THE STUDY AREA}

Mashhad is located in the center of Khorasan Razavi province, northeast of Iran, 966 $\mathrm{km}$ from Tehran. Mashhad has expanded at 35 degrees 43 minutes to 37 degrees 8 minutes' latitude and

59 degrees 15 minutes to 60 degrees 36 minutes. The city is located between the two Binaloud Mountains and Hezar Masjed. Its altitude is 985 meters, its area is about $351.4 \mathrm{~km} 2$ and its

population is about 3,057,679 in 2017 (BAZM AZMOON, 2007). Mehrgan Town as a separate urban area is located in the area of three municipalities of Mashhad and its distance

from the holy shrine of Imam Reza, is $16 \mathrm{~km}$. This area is located in the northeast part of Mashhad city at the center of Qoroghi village. The town is located as a detached urban area in northeast Mashhad. The original core of the settlement dates back to Hossein Abad Village in Qoroghi, which has now become an urban area with numerous buildings.

Table 1- Population of Mashhad from 1986 to 2016

\begin{tabular}{ccccccc}
\hline Year & $\mathbf{1 9 8 6}$ & $\mathbf{1 9 9 1}$ & $\mathbf{1 9 9 6}$ & $\mathbf{2 0 0 6}$ & $\mathbf{2 0 1 1}$ & $\mathbf{2 0 1 6}$ \\
\hline Population & 1463508 & 1759287 & 1866300 & 2427316 & 2766258 & 3057679 \\
\hline \multirow{2}{*}{ Year } & \multirow{2}{*}{$1976-1986$} & $1986-$ & $1991-$ & $1996-$ & $2006-$ & $2011-$ \\
& & 1991 & 1996 & 2006 & 2011 & 2016 \\
\hline \multirow{2}{*}{ Growth Rate } & 3.75 & 1.41 & 1.73 & 1.6 & 1.3 & 1.2 \\
\hline
\end{tabular}

Source; Authors (2020)

\section{$4 \quad$ RESULTS}

Generally, in the research findings section, affecting the dimensions of Mehregan residents' satisfaction with Mehr housing in Mehregan Township of Mashhad, including: 
economic, environmental, physical and social criteria and has been addressed in the questionnaire questions so far. The information obtained can be analyzed by Spearman method.

Figure 2- Housing criteria in this study

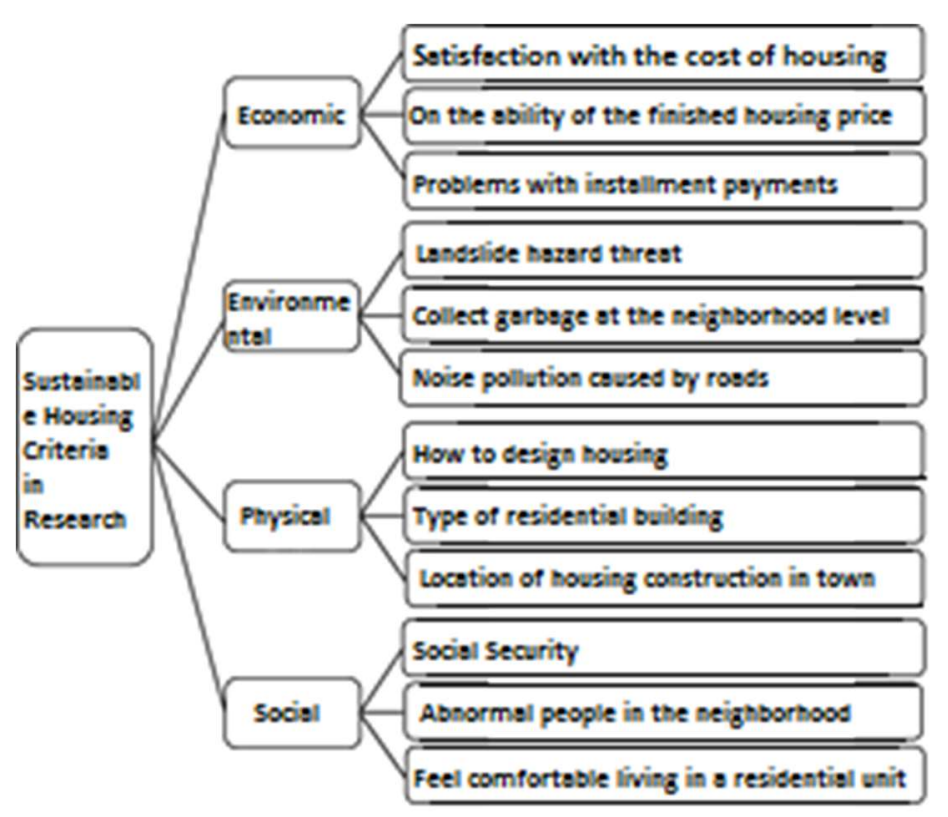

Source: Auhtors (2020)

Statistical analysis of residents and experts questionnaires

\subsection{Analyzing the residents' views on the housing situation of Mehregan Town}

Table 2- Number and Percentage of Respondents Satisfied with Finished Housing Price

\begin{tabular}{cccc}
\hline \multirow{2}{*}{ Index } & Comments & Abundance & $\begin{array}{c}\text { Abundance } \\
\text { Percentage }\end{array}$ \\
\hline $\begin{array}{c}\text { To what extent are you satisfied } \\
\text { with the cost of your home? }\end{array}$ & Very High & $\mathbf{0}$ & $\mathbf{0}$ \\
\cline { 2 - 4 } & High & 25 & 6.8 \\
\cline { 2 - 4 } & Average & 140 & 38.3 \\
\cline { 2 - 4 } & Low & 43 & 11.7 \\
\cline { 2 - 4 } & Very Low & 158 & 43.2 \\
\cline { 2 - 4 } & Total & 366 & 100.0 \\
\hline
\end{tabular}

Source: Authors (2020) 
According to the table above, for half of the residents, the cost of housing has been below their affordability and capability.

Table 4- Number and Percentage of Respondents Difficult to Pay Installments

\begin{tabular}{cccc}
\hline Index & Comments & Abundance & $\begin{array}{c}\text { Abundance } \\
\text { Percentage }\end{array}$ \\
\hline $\begin{array}{c}\text { Have you ever been in } \\
\text { trouble with housing } \\
\text { payment installment? }\end{array}$ & Yes & 208 & 56.8 \\
\cline { 2 - 4 } & No & 158 & 43.2 \\
\hline
\end{tabular}

Source: Authors (2020)

According to the table above, more than half of residents have difficulty paying their housing installments.

\subsection{Analyzing managers' views on Mehregan Town housing}

Managers' views on housing design patterns in Mehregan Town of Mashhad include several cases, each of which is examined separately.

Table 5- Number and Percentage of Respondents Concerning the Fairness of Finished Housing Prices

\begin{tabular}{cccc}
\hline \multirow{2}{*}{ Index } & Comments & Abundance & $\begin{array}{c}\text { Abundance } \\
\text { Percentage }\end{array}$ \\
\hline How fair do you think the price of & & 0 & 0 \\
\cline { 2 - 4 } housing in this neighborhood is? & Very High & 0 & 0 \\
\cline { 2 - 4 } & High & 18 & 56.3 \\
\cline { 2 - 4 } & Average & 4 & 12.5 \\
\cline { 2 - 4 } & Low & 10 & 31.3 \\
\cline { 2 - 4 } & Very Low & 32 & 100.0 \\
\hline
\end{tabular}

Source: Authors (2020) 
According to the table above, most managers (about $56.3 \%$ ) think that the cost of housing in this neighborhood is not fair.

Table 6- Number and Percentage of Respondents to Affordable Housing Costs

\begin{tabular}{cccc}
\hline Index & Comments & Abundance & Abundance Percentage \\
\hline \multirow{2}{*}{$\begin{array}{c}\text { Do you think the cost of } \\
\text { housing is in ability of the } \\
\text { people? }\end{array}$} & Yes & 7 & 21.9 \\
\cline { 2 - 4 } & No & 25 & 78.1 \\
\cline { 2 - 4 } & Total & 32 & 100.0 \\
\hline
\end{tabular}

Source: Authors (2020)

For most managers (about 78.1\%), the cost of housing has not been as affordable as it could be.

Table 7- Number and Percentage of Respondents in Reaching This Settlement

\begin{tabular}{cccc}
\hline Index & Comments & Abundance & $\begin{array}{c}\text { Abundance } \\
\text { Percentage }\end{array}$ \\
\hline \multirow{2}{*}{$\begin{array}{c}\text { How fair was the access to } \\
\text { housing for everyone in this } \\
\text { neighborhood? }\end{array}$} & Very High & $\mathbf{0}$ & $\mathbf{0}$ \\
\cline { 2 - 4 } & High & 5 & 15.6 \\
\cline { 2 - 4 } & Average & 4 & 12.5 \\
\cline { 2 - 4 } & Low & 11 & 34.4 \\
\cline { 2 - 4 } & Very Low & 12 & 37.5 \\
\hline & Total & 32 & 100.0 \\
\hline
\end{tabular}

Source: Authors (2020)

The results showed that most managers (about 37.5\%) believe that fairness of access to housing for all people in this neighborhood is too low.

Hypothesis: It seems that residential units built in Mehregan town of Mashhad do not fully comply with sustainable housing standards.

The one variable Chi-square test was used to test the above hypothesis. The results of this test are presented in the following table: 
(Continue...)

Table 8- Evaluation of Compliance of Residential Units Constructed in Mehregan Town of Mashhad with Available Housing Standards and Criteria for Vulnerable People

\begin{tabular}{|c|c|c|c|c|}
\hline Group & Compliance rate & $\begin{array}{l}\text { Observed } \\
\text { Abundanc } \\
\text { e }\end{array}$ & $\begin{array}{c}\text { Abundanc } \\
\text { e } \\
\text { Percentage }\end{array}$ & $\begin{array}{l}\text { Expected } \\
\text { abundance }\end{array}$ \\
\hline \multirow[t]{7}{*}{ Residents } & Low & 222 & 60.7 & 122.0 \\
\hline & Average & 119 & 32.5 & 122.0 \\
\hline & High & 25 & 6.8 & 122.0 \\
\hline & Total & 366 & 100.0 & 366 \\
\hline & Chi-square Statistics & & 159.164 & \\
\hline & Freedom Degree & & 2 & \\
\hline & Significance Level & & 0.000 & \\
\hline \multirow[t]{7}{*}{ Managers } & Low & 26 & 81.3 & 16.0 \\
\hline & Average & 6 & 18.8 & 16.0 \\
\hline & High & 0 & 0 & 0 \\
\hline & Total & 32 & 100.0 & 32 \\
\hline & Chi-square Statistics & & 12.500 & \\
\hline & Freedom Degree & & 1 & \\
\hline & Significance Level & & 0.000 & \\
\hline
\end{tabular}

Source: Authors (2020) 
(Continue...)

Diagram 1- Compliance of residential units built in Mehregan Town of Mashhad with affordable housing standards for vulnerable groups

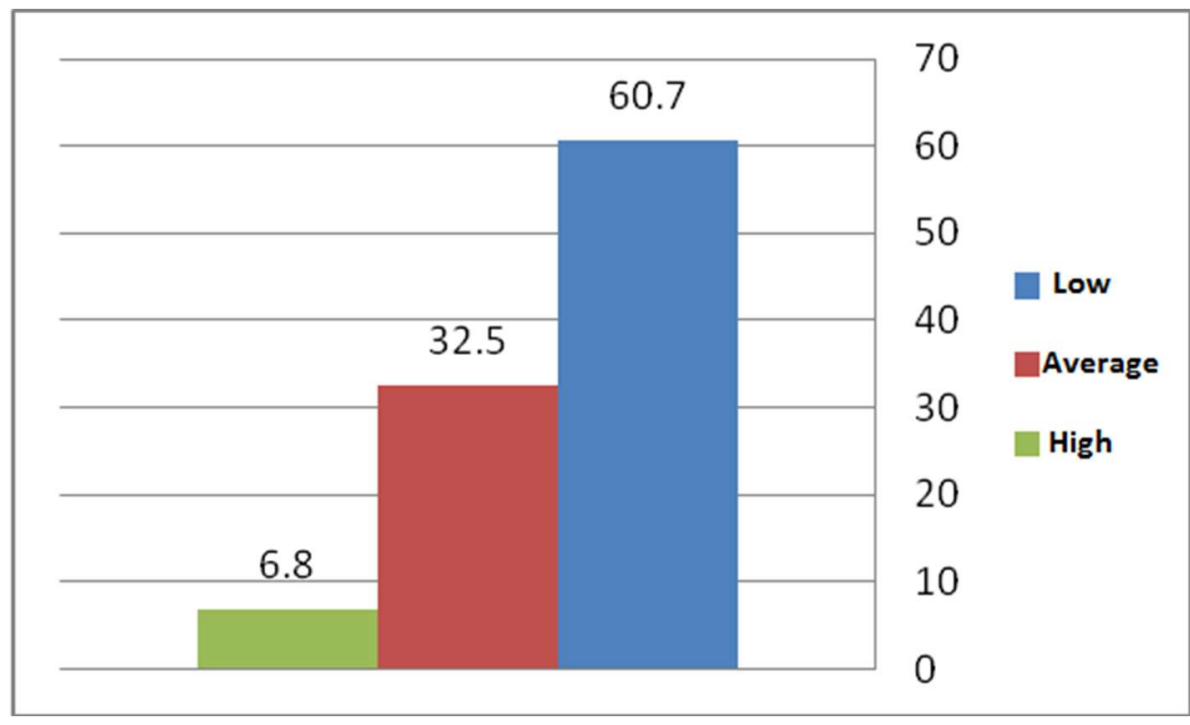

Source: Authors (2020)

Diagram 2- Compliance of residential units built in Mashhad Mehregan town with affordable housing standards for vulnerable groups 


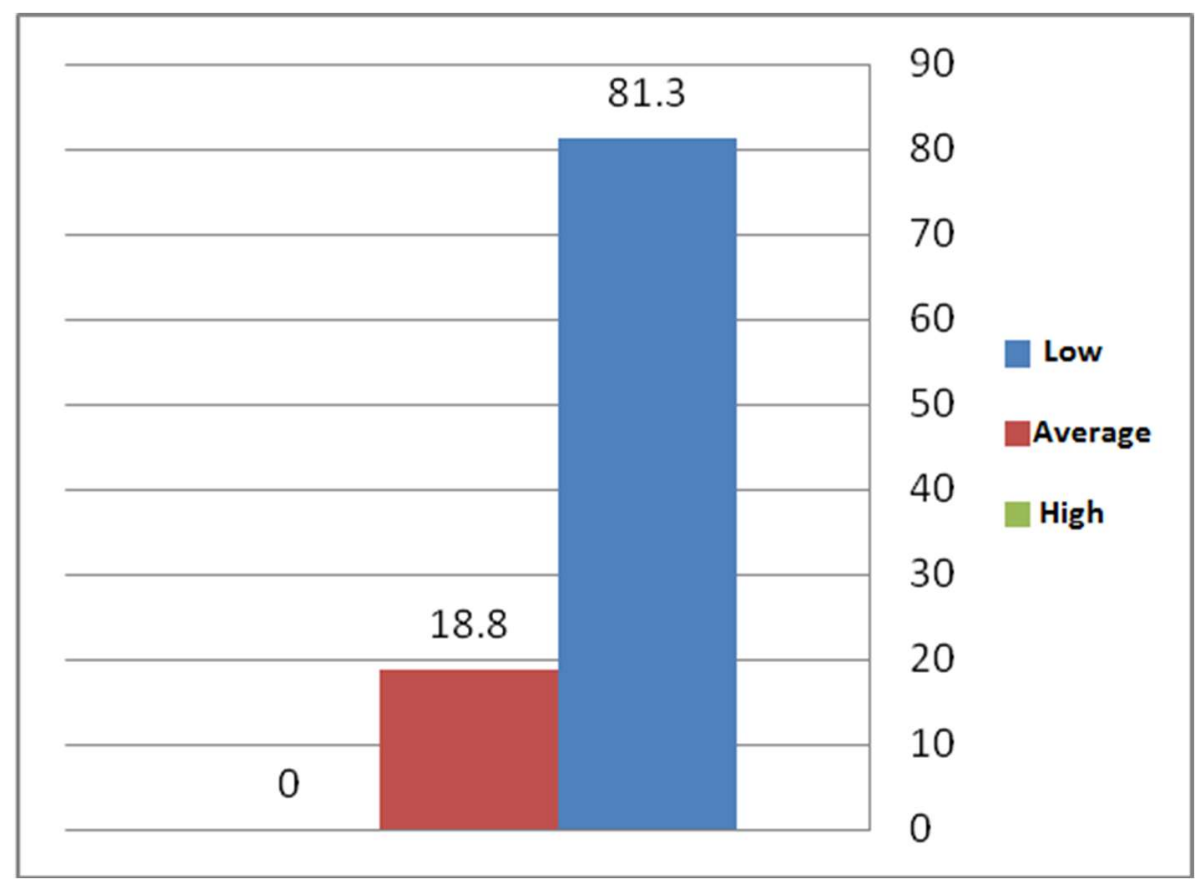

Source: Authors (2020)

According to the table above, the level of significance for the resident group is equal to 0.000 and less than 0.05 , so there is a significant difference between the frequency of respondents in the three groups of low, medium and high, with 95\% confidence. On the other hand, the frequency of low-commented residents was 222 and above all. That is, most of the residents are not satisfied with their housing in Mehregan Township and they believe that the residential units built in Mehregan Township of Mashhad are not in compliance with the standards of sustainable housing. So with $95 \%$ confidence we can say:

Most of the residents are not satisfied with their housing in Mehregan Township and believe that the residential units built in Mehregan Township of Mashhad are not in compliance with sustainable housing standards.

The level of significance for the group of managers is equal to 0.000 and less than 0.05 , so there is a $95 \%$ confidence difference between the frequency of respondents in the three groups of low, medium and high. On the other hand, the frequency of low-perceived managers is 26 and above all. That is, most managers believe that residential units built in Mehregan town of Mashhad do not comply with sustainable housing standards. So with $95 \%$ confidence we can say: 
According to managers: Residential units built in Mehregan town of Mashhad do not fully comply with sustainable housing standards.

According to the research we will conclude with the questionnaire and its results, we should first consider the questions of the questionnaire in terms of reliability and standardization, as it can be seen that the mean alpha obtained in the questionnaire is 0.980 indicating that Questionnaire of this research has desirable reliability level.

Figure 3- Expert Opinions on the Problems of Operation of Mehregan Town Buildings

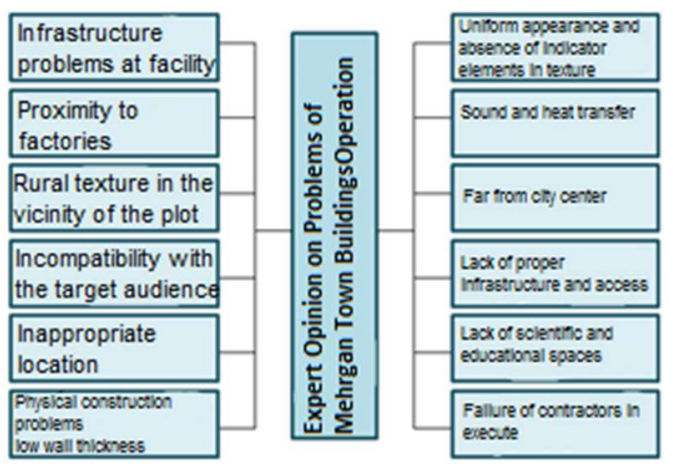

Source: Authors (2020)

\section{CONCLUSION}

Mehregan housing policy has been one of the most important housing policies in the 9th and 10th governments. The policy is aimed at providing housing and shelter for lowincome groups and deciles. Mehregan Housing Despite its strengths and weaknesses, given the enormous volume of construction across the country, housing is a major event in the country's architectural and urban history and requires much study and criticism. But the linear, top-down decision-making process, and the lack of need assessment of the inhabitants of these types of projects, which are actually the main beneficiaries, result in waste of resources and energy. Other challenges in providing housing for residents are lack of location due to restriction of land selection and consequently problems with access to utilities, and access to workplace facilities. But perhaps more important than the physical factors mentioned in this article, according to residents and experts, are their dissatisfaction with housing in terms of compliance with sustainable housing standards. 


\section{SUGGESTIONS}

Here are some suggestions for achieving sustainable housing in Mehregan Town area of Mashhad:

- Choosing complex management with the participation of residents of the town.

- Facilitate residents' participation in designing and construction sites locating.

- Establishment of recreational and sports equipment for children in Mehregan town.

- Improving the quality of settlement facilities.

- Improving the accessibility of settlements to public transport services such as buses and taxis.

- Improvement of the sanitation status of the town, such as cleaning the streets.

- Establishment of service centers, especially health centers in the town.

- Establish basic amenities such as school, police station and daily shopping center within the town.

- Creating leisure centers and spaces and increasing cultural and educational centers.

- Allocate part of the lands of Mehregan Town to green spaces and playgrounds for children.

- Further monitoring of the process of unit construction and quality of used materials.

- Preventing social stratification, especially for the low-income areas, in order not to label these areas in the future as slum areas, and to prevent undue growth of cities outside the legal or city limits.

- Providing lighting at night.

- Strengthening the sewage disposal system to improve the condition of settlements.

- Improving the quality of passages.

- Enhance the design quality, create diversity and beautify the space.

- Increasing the quantity and quality of furniture and enhancing the green space of the town and thus enhancing the socialization of Mehregan housing.

\section{REFERENCES}


ASADPOUR, A. Sustainable Patterns in Iranian Desert Architecture, Ma Journal, No. 25, pp, 89-100, 2006.

ATHARI, K. Planning and Shortcomings of Planning in Low-Income Housing, Journal of Housing Economics, No. 34, pp, 29-35, 2006.

AZADKHANI, P. AND TAHMASEBI KIA, Z. Journal of Urban Research and Planning, Seventh Year, No. 27, pp, 178-187, 2016.

AZIZI, MOHAMMAD, M. Analysis of the Situation and Transformation of Urban Housing in Iran, Journal of Tehran Fine Arts University, No. 23, pp, 56-70, 2004.

BAZM AZMOON, A. How to Establish and Manage Mehr Housing Cooperatives, Tehran: Venus Publishing, 2007.

GHARAKHLOU, A. the Indicators of Urban Sustainable Development. Geography and Regional Development Magazine, No. 8, pp, 65-71, 2006.

HATAMI NEJAD, H. Survey of Unofficial Housing Indicators in Iran: Case Study: Sheikh Abad, Qom, Geographical Research, 58, pp, 13-20, 2005.

KEARNEY, A. R. Residential development patterns and neighborhood satisfaction: impacts of density and nearby nature. Journal of Environment and Behavior, No. 38, pp. 112-139, 2006.

MAHMOUDI, M. M. Housing Development in harmony with sustainable development, first edition, Tehran: Tehran University Press, 2009.

MALEKI, S., SHEIKHI, H. Analysis and Classification of Indicators and Determination of Development Priorities in Provinces of Iran Using Factor Analysis and Cluster Analysis, Geography and Planning Journal, No. 29, pp. 90-99, 2009.

POURMOHAMMADI, M. R. Housing Planning. Fourth Edition, Tehran: SAMT Publication, 2006.

RAFIEIAN, M., ASGARIZADEH, Z., AND ASGARIZADEH, A. Measuring Residents' Satisfaction in Navab Neighborhood, Human Geographical Research, No. 67, pp, 45-49, 2009.

ZABETIAN, E., SADEGHI, A., AND HOSSEIN ABADI, S. Survey of Residents' Satisfaction with Mehr Housing Projects with Emphasis on Evaluation of Objective Components (Case Study: Mehr Housing Project of Qom), Scientific - Research Journal Iranian Architecture and Urban Development, No. 14, PP. 34-59, 2017.

\section{AUTHORSHIP CONTRIBUTIONS}

\section{1 - Mohammad Reza Daime Kar:}

PhD Student of Geography and Urban Planning mohamadrezadaime@gmail.com | https://orcid.org/0000-0002-3221-1588 
Contribuition: Data curation, Formal Writing - original draft, Analysis, Funding acquisition

\section{2 - Mohammad Ali Ahmadian:}

\section{Associate Professor}

Ahmadian@ferdowsi.um.ac.ir | https://orcid.org/0000-0002-0978-4804

Contribuition: Project administration, Writing - review \& editing, Investigation

\section{3 - Katayoun Alizadeh:}

Assistant Professor

E-mail: katayoon_alizadeh@yahoo.com | https://orcid.org/0000-0002-0174-6280

Contribuition: Conceptualization, Supervision, Methodology, Software

\section{4 - Hossein Hataminezhad:}

Assistant Professor

E-mail: hataminejad@ut.ac.ir | E-mail: hataminejad@ut.ac.ir

Contribuition: Validation, Visualization, Resources

\section{HOW TO QUOTE THIS ARTICLE}

KAR, M. R. D; AHMADIAN, M. A; ALIZADEH, K. Measuring the Satisfaction of Residents of Mehregan Township of Mashhad from Sustainable Housing Perspective Revista de gestão, educação e tecnologia ambiental. Santa Maria, v.25, e10, 2021. Available from: https://doi.org/10.5902/2236117063796. Accessed: Month Abbreviated. Day, year. 